\title{
Roles and Responsibilities of the Orthopaedic Community and the Society During COVID-19 Pandemic
}

\author{
Raju Vaishya $^{1} \cdot$ Abhishek Vaish $^{1}$
}

Received: 2 April 2020 / Accepted: 4 April 2020 / Published online: 14 April 2020

(c) Indian Orthopaedics Association 2020

Sir,

Although the Orthopaedic surgeons are not in the frontline of the battle with COVID-19, still need to be sensitizing about their role and responsibilities during this pandemic. Several Orthopaedic and Surgical Societies and Associations have issued the guidelines for their members to follow during this pandemic [1-3]. The salient features of these guidelines are to:

1. Only the absolute emergency cases are to be operated upon.

2. Non-emergency cases should be treated non-operatively, as far as possible.

3. Avoid unnecessary hospital visits of the patients and encourage doing telemedicine consultations, as far as possible.

4. Take maximum degree of universal precautions yourself, during the hospital work and also protect the other healthcare professionals working with you.

The Royal College of Surgeons of England has recently given broad guidelines for the good practices for the surgeons and the surgical teams during COVID-19 pandemic [4]:

(A) Adapting surgical services by triage of non-emergency surgery, provision of surgery in the Clinical networks, optimization of the rotas of the team members, and to conduct virtual outpatient clinics.

(B) Working in an extended scope of practice by working beyond one's regular scope of practice as part of a team, engaging retired surgeons and trainees.

Raju Vaishya

raju.vaishya@gmail.com

1 Department of Orthopaedics and Joint Replacement Surgery, Indraprastha Apollo Hospitals, New Delhi 110076, India
(C) Caring for patients at the end of life.

(D) Protecting the workforce by infection prevention methods, and ensuring surgeons' and surgical teams' wellbeing.

COVID-19 is a highly contagious disease and its pandemic is spreading like a wild fire across the world. Most countries have enforced severe restrictions in their respective zones to contain the menace of this disease. It surely feels like a world-war situation. The frontline soldiers in this battle against the Novel Corona Virus are the healthcare workers (doctors, nurses and other medical staff). It is becoming obvious that the incidence of infection in these frontline health workers is rampant across many countries, to the extent that several deaths have also been reported amongst them. There are several reasons for making the healthcare workers more susceptible to this disease: (a) overstretched health care facilities, (b) acute shortage of essential equipments like respirator masks, PPE, and ventilators, (c) high viral load in the hospitals. Sadly, these 'brave soldiers of the society are also facing social ostracisation from their landlords and society [5].

It is important to realize that these healthcare workers are the ones which are on the frontline in this war against the deadly virus and must be supported whole heartedly by the society and the governments, in this time of crisis They must be provided adequate numbers of good-quality PPEs and insurance cover, to be able fight in this battle for us all. There has been an acute shortage of these essential PPEs for them and providing them with substandard PPEs (similar to rain coats!) is not the solution to overcome the crisis. It is akin to "sending soldiers into the war with misfiring guns" [5].

If we are to win this battle against the novel corona virus then we need to support and provide necessary resources for the healthcare workers just as the Nation support its soldiers in a war. 


\section{Compliance with Ethical Standards}

Conflict of interest The authors declare that they have no conflict of interest to disclose.

Ethical standard statement This article does not contain any studies with human participants or animals, performed by any of the authors.

Informed consent For this type of study a formal consent is not required.

\section{References}

1. Management of patients with urgent Orthopaedic conditions and trauma during the coronavirus pandemic. British Orthopaedic Association. 24 March 2020. https://www.boa.ac.uk/resources/ covid-19-boasts-combined.html.

2. Guidance for surgeons working during the COVID-19 pandemic. The Surgical Royal Colleges of the United Kingdom and Ireland. 20th March 2020. https://www.rcseng.ac.uk/coronavirus/joint -guidance-for-surgeons/.

3. Indian Orthopaedic Association. COVID-19 IOA guidelines. 25th March 2020. https://www.ioaindia.org/COVID-19IOAguidelines .pdf.

4. COVID-19: Good practice for surgeons and surgical teams. Royal College of Surgeons of England. Published on 1st April 2020. https://www.rcseng.ac.uk/standards-and-research/stand ards-and-guidance/good-practice-guides/coronavirus/?utm_ campaign=1360309_COVID-19\%3A\%20Good\%20Practice $\% 20$ for $\% 20$ Surgeons $\% 20$ and $\% 20$ Surgical $\% 20$ Teams\&utm mediu $\mathrm{m}=$ dotmailer\&utm_source $=$ email marketing $\& \mathrm{dm}$ $\mathrm{i}=4 \mathrm{D} 4 \mathrm{~N}, \mathrm{~T} 5 \mathrm{MD}, 1186 \mathrm{IW}, 3 \mathrm{IJ} 2 \mathrm{~A}, 1 \mathrm{~A}$.

5. Soldiers in White Coat (Editorial). The Times of India. Published on 2nd April 2020. https://epaper.timesgroup.com/Olive/ODN/ TimesOfIndia/\#.

Publisher's Note Springer Nature remains neutral with regard to jurisdictional claims in published maps and institutional affiliations. 